\title{
Hubungan Higiene Personal terhadap Kejadian Pitiriasis Versikolor pada Mahasiswa Laki-laki Fakultas Kedokteran Unsrat
}

\author{
${ }^{1}$ Jibrando Tumilaar \\ ${ }^{2}$ Pieter L. Suling \\ ${ }^{2}$ Nurdjannah J. Niode
}

\author{
${ }^{1}$ Program Studi Pendidikan Dokter Fakultas Kedokteran Universitas Sam Ratulangi Manado \\ ${ }^{2}$ Bagian Ilmu Kesehatan Kulit dan Kelamin Fakultas Kedokteran \\ Universitas Sam Ratulangi Manado \\ Email: emeltumilaar@gmail.com
}

\begin{abstract}
Pityriasis versikolor is a skin fungal infection that is quite common in Indonesia as a tropical country with a hot and humid climate, especially if the personal hygiene is not good enough. This study was aimed to evaluate the relationship between personal hygiene and the incidence of pityriasis versicolor among male students of the Faculty of Medicine, Sam Ratulangi University. This was a descriptive analytical stuudy with a cross-sectional design. Subjects were 42 medical students of batch 2015-2018. Personal hygiene was determined by using questionnaires and diagnosis of pityriasis versicolor was confirmed based on clinical and Wood lamp examinations. The results showed that pityriasis versicolor was diagnosed in two subjects (4.8\%). The Fisher's exact test obtained a significancy value of 0.003 which indicated that there was a significant relationship between personal hygiene and pityriasis versicolor. Conclusion: There was a significant relationship between personal hygiene and the occurence of pityriasis versicolor. Poor personal hygiene was a risk factor of pityriasis versicolor.
\end{abstract}

Keywords: pityriasis versicolor, personal hygiene, students

\begin{abstract}
Abstrak: Pitiriasis versikolor adalah infeksi jamur kulit yang cukup banyak ditemukan di Indonesia yang merupakan negara tropis beriklim panas dan lembab, apalagi bila higiene kurang sempurna. Penelitian ini bertujuan untuk mengetahui higiene personal terhadap kejadian pitiriasis versikolor pada mahasiswa laki-laki Fakultas Kedokteran Universitas Sam Ratulangi. Jenis penelitian ialah deskriptif analitik dengan desain potong lintang. Subjek penelitian ialah 42 mahasiswa Kedokteran Umum angkatan 2015-2018. Tingkat higiene personal diambil dari kuesioner dan diagnosis pitiriasis versikolor ditegakkam berdasarkan pemeriksaan klinis dan lampu Wood. Hasil penelitian memperlihatkan kejadian pitiriasis versikolor pada dua subyek penelitian $(4,8 \%)$. Uji Fisher's exact test mendapatkan nilai signifikansi 0,003 yang menunjukkan adanya hubungan bermakna antara higiene personal dan pitiriasis versikolor. Simpulan: Terdapat hubungan bermakna antara higiene personal dan pitiriasis versikolor. Higiene personal yang buruk merupakan faktor risiko terjadinya pitiriasis versikolor.
\end{abstract}

Kata kunci: pitiriasis versikolor, higiene personal, mahasiswa

Masalah kesehatan khususnya penyakit jamur menjadi salah satu penyakit kulit yang paling banyak diderita oleh masyarakat yang tinggal di daerah beriklim panas dan lembab yang mengakibatkan daerah tropis memiliki prevalensi setinggi $40 \%$ dan frekuensi yang lebih tinggi selama bulan musim panas. ${ }^{1}$

Infeksi jamur pada kulit biasanya terjadi pada bagian kulit yang paling luar. Hal ini disebabkan jenis jamur ini tidak dapat mengeluarkan zat yang dapat men- 
cerna keratin kulit dan tetap hanya menyerang lapisan kulit yang paling luar. Penyakit kulit yang termasuk golongan ini yaitu pitiriasis versikolor. ${ }^{2}$

Pitiriasis versikolor adalah infeksi jamur superfisial pada lapisan tanduk kulit yang disebabkan oleh Malassezia furfur atau Pityrosporum orbiculare. Infeksi ini bersifat menahun, ringan, dan biasanya tanpa peradangan. Pitiriasis versikolor dapat mengenai muka leher, badan, lengan atas, ketiak, paha, dan lipat paha. ${ }^{3}$ Tidak ada perbedaan berdasarkan jenis kelamin tetapi terdapat kerentanan berdasarkan usia, yakni lebih banyak ditemukan pada remaja dan dewasa muda. ${ }^{4}$ Berdasarkan penelitian, mayoritas yang terinfeksi berada pada dekade dua dan tiga kehidupan. ${ }^{5}$

Di Indonesia kelainan ini merupakan yang terbanyak ditemukan di antara berbagai penyakit kulit akibat jamur. Diperkirakan $40-50 \%$ populasi di negara tropis terkena penyakit ini, sedangkan di negara subtropis yaitu Eropa Tengah dan Utara hanya $0,5-1 \%$ dari semua penyakit jamur. ${ }^{6}$ Di Jakarta golongan penyakit ini sepanjang masa selalu menempati urutan ke dua setelah dermatitis. Di daerah lain, seperti Padang, Bandung, Semarang, Surabaya, dan Manado, keadaannya sama yaitu menempati urutan ke 2 sampai ke 4 terbanyak dibandingkan golongan penyakit lainya. ${ }^{3}$

Di RSUP Prof. Dr. R. D. Kandou Manado, pada periode Januari-Desember 2013 tercatat jumlah pasien laki laki (58\%) lebih banyak dibandingkan perempuan (52\%). Dilihat dari segi usia 15-24 tahun dan 25-44 tahun yang terbanyak (masingmasing 30,6\%), sedangkan dari segi pekerjaan paling banyak terdapat pada pasien dengan pekerjaan swasta $(27,8 \%)$ dan PNS $(16,7 \%)$. Dari segi warna lesi terbanyak ialah hipopigmentasi $(78 \%)^{7}$

Higiene personal adalah pengetahuan tentang usaha kesehatan perorangan untuk memelihara kesehatan diri sendiri, memperbaiki dan mempertinggi nilai kesehatan, serta mencegah timbulnya penyakit. Beberapa faktor yang memengaruhi higiene personal antara lain ialah citra tubuh, praktik sosial, status sosial ekonomi, pengetahuan, budaya, pilihan pribadi, dan kondisi fisik. ${ }^{8}$ Higiene personal harus menjadi bagian kebiasaan kehidupan sehari-hari, dimulai dengan hal mudah yaitu mencuci tangan, menyikat gigi, dan menganti pakaian kotor dapat menjaga tubuh kita terhindar dari jamur. ${ }^{9}$

Mahasiswa diartikan sebagai individu yang sedang menuntut ilmu di tingkat perguruan tinggi, baik yang belajar di perguruan tinggi negeri maupun swasta atau lembaga lain yang setingkat dengan perguruan tinggi. Mahasiswa memiliki kedudukan istimewa dalam masyarakat terutama peranya sebagai agen perubahan dalam hal ini dikaitkan dengan personal higiene. Penelitian ini bertujuan untuk mengetahui hubungan antara higiene personal dengan angka terjadinya penyakit pitiriasis versikolor pada mahasiswa lakilaki Fakultas Kedokteran Universitas Sam Ratulangi.

\section{METODE PENELITIAN}

Jenis penelitian ini ialah analitik observasional dengan metode penelitian kuantitatif dan desain potong lintang. Subyek penelitian ialah mahasiswa lakilaki Fakultas Kedokteran Universitas Sam Ratulangi angkatan 2015-2018. Penelitian ini dilakukan dengan membagikan kuesioner untuk menilai tingkat higiene personal dan pemeriksaan lampu Wood untuk menegakkan diagnosis pitiriasis versikolor.

\section{HASIL PENELITIAN}

Tabel 1 menampilkan karakteristik subyek penelitian berdasarkan usia. Subyek terbanyak berusia 20 tahun yaitu 13 dari 42 subyek $(31,0 \%)$ dan paling sedikit berusia 22 tahun yaitu 1 subyek $(2,4 \%)$, dengan usia minimum 17 tahun dan maksimum 22 tahun.

Tabel 2 memperlihatkan dari 42 subyek didapatkan 2 orang menderita pitiriasis versikolor yaitu yang berusia 18 tahun $(2,4 \%)$ dan 19 tahun $(2,4 \%)$. 
Tabel 1. Distribusi frekuensi karakteristik subyek penelitian berdasarkan usia

\begin{tabular}{ccc}
\hline Usia & Frekuensi & Persentase $\mathbf{( \% )}$ \\
\hline 17 & 2 & 4,8 \\
18 & 10 & 23,8 \\
19 & 11 & 26,2 \\
20 & 13 & 31,0 \\
21 & 5 & 11,9 \\
22 & 1 & 2,4 \\
Total & 42 & 100 \\
\hline
\end{tabular}

Tabel 3 memperlihatkan bahwa berdasarkan jumlah mandi sehari, subyek terbanyak dengan jumlah mandi 2 kali sehari yaitu sebanyak 32 orang $(76,2 \%)$. Berdasarkan cara mandi, subyek terbanyak ialah mandi dengan air dan sabun kemudian menggosok kulit dan disiram sampai bersih yaitu sebanyak 39 orang $(92,9 \%)$. Berdasarkan kebiasaan menggunakan sabun, subyek terbanyak ialah yang menggunakan sabun sendiri sebanyak 33 orang $(78,6 \%)$. Untuk yang mengalami keluhan gatal di kulit sebanyak 1 orang $(2,4 \%)$, adanya bercak di kulit sebanyak 1 orang $(2,4 \%)$, sedangkan adanya kulit mengelupas, bersisik dan kering tidak ada $(0,0 \%)$.

Tabel 2. Distribusi frekuensi kejadian pitiriasis versikolor berdasarkan usia

\begin{tabular}{cccc}
\hline Usia & $\begin{array}{c}\text { Pitiriasis } \\
\text { Ya }(\%)\end{array}$ & $\begin{array}{c}\text { versikolor } \\
\text { Tidak }(\%)\end{array}$ & $\begin{array}{c}\text { Total } \\
(\%)\end{array}$ \\
\hline 17 & $0(0,0)$ & $2(4,8)$ & $2(4,8)$ \\
18 & $1(2,4)$ & $9(21,4)$ & $10(19,0)$ \\
19 & $1(2,4)$ & $11(26,2)$ & $12(28,6)$ \\
20 & $0(0,0)$ & $12(28,6)$ & $12(33,3)$ \\
21 & $0(0,0)$ & $5(11,9)$ & $5(11,9)$ \\
22 & $0(0,0)$ & $1(2,4)$ & $1(2,4)$ \\
Total & $2(4,8)$ & $40(95,2)$ & $42(100)$ \\
\hline
\end{tabular}

Tabel 3. Distribusi frekuensi kebersihan kulit responden

\begin{tabular}{lcc}
\hline \multicolumn{1}{c}{ Kebersihan Kulit } & Frekuensi & Persentase \\
\hline Jumlah mandi dalam sehari & 5 & 11,9 \\
1 kali & 32 & 76,2 \\
2 kali & 5 & 11,9 \\
3 kali & 0 & \\
Cara mandi & 3 & 7,1 \\
$\quad$ Mandi dengan menyiram air secukupnya & & \\
Mandi dengan air lalu menggosok kulit dan seluruh tubuh disiram & 39 & 92,9 \\
sampai bersih & & \\
Mandi dengan air dan sabun,menggosok kulit dan seluruh tubuh & & \\
disiram sampai bersih & 0 & 0 \\
Kebiasaan menggunakan sabun & 9 & 21,4 \\
Tidak menggunakan sabun & 33 & 78,6 \\
Menggunakan sabun bergantian dengan keluarga & & \\
Menggunakan sabun sendiri & 34 & 81,0 \\
Keluhan gatal-gatal di kulit & 7 & 16,7 \\
Tidak & 1 & 2,4 \\
Kadang-kadang & & \\
Ya & 32 & 76,2 \\
Keluhan adanya bercak di kulit & 9 & 21,4 \\
Tidak & 1 & 2,4 \\
Kadang-kadang & & \\
Ya & 0 & 0,0 \\
Keluhan adanya kulit mengelupas, bersisik dan kering & 11 & 26,2 \\
Ya & 31 & 73,8 \\
Kadang-kadang & & \\
Tidak & & \\
\hline
\end{tabular}


Tabel 4 memperlihatkan bahwa tingkat kebersihan kulit dari subyek penelitian yang terbanyak ialah termasuk kategori baik yaitu sebanyak 39 orang $(92,9 \%)$.

Tabel 5 menunjukkan bahwa subyek yang jarang mengganti baju tidak ada, ganti baju 1 kali sehari sebanyak 12 orang $(28,6 \%)$, ganti baju $\geq 2$ kali sehari sebanyak 30 orang $(71,4 \%)$. Untuk subyek yang tidak mengganti baju setelah berkeringat tidak ada $(0,0 \%)$ sedangkan yang mengganti baju sebanyak 23 orang $(54,8 \%)$.

Tabel 6 memperlihatkan bahwa tingkat kebersihan berdasarkan cara meletakkan handuk yang terbanyak adalah dijemur di luar yaitu sebanyak 26 subyek $(61,9 \%)$.

Tabel 7 menunjukkan bahwa dari 42 subyek, terdapat dua subyek yang terkena pitiriasis versikolor $(4,8 \%)$ sedangkan 40 orang tidak terkena pitiriasis versikolor
(95,2\%). Dari 42 subyek, terdapat 39 orang dengan tingkat kebersihan diri baik $(92,9 \%)$ dan 3 orang dengan tingkat kebersihan diri buruk $(7,1 \%)$. Pada dua subyek yang positif pitiriasis versikolor, didapatkan keduanya dengan tingkat kebersihan diri buruk $(4,8 \%)$, sedangkan 40 subyek yang tidak terkena pitiriasis versikolor, hanya satu orang dengan tingkat kebersihan diri buruk $(2,4 \%)$.

Tabel 4. Distribusi frekuensi tingkat kebersihan kulit subyek penelitian

\begin{tabular}{ccc}
\hline $\begin{array}{c}\text { Kebersihan } \\
\text { kulit }\end{array}$ & Jumlah & $\begin{array}{c}\text { Persentase } \\
(\boldsymbol{\%})\end{array}$ \\
\hline Baik & 39 & 92,9 \\
Buruk & 3 & 7,1 \\
Total & 42 & 100 \\
\hline
\end{tabular}

Tabel 5. Distribusi frekuensi tingkat kebersihan pakaian responden

\begin{tabular}{lcc}
\hline Kebersihan pakaian & Frekuensi & $\begin{array}{c}\text { Persentase } \\
(\%)\end{array}$ \\
\hline Mengganti baju dalam sehari & 0 & 0 \\
$\quad$ Jarang & 12 & 28,6 \\
1 kali sehari & 30 & 71,4 \\
$\quad$ 2 kali sehari & & \\
Mengganti baju setelah berkeringat & 0 & 0,0 \\
$\quad$ Tidak & 19 & 45,2 \\
Kadang-kadang & 23 & 54,8 \\
Ya & & \\
\hline
\end{tabular}

Tabel 6. Distribusi frekuensi tingkat kebersihan handuk responden

\begin{tabular}{lcc}
\hline \multicolumn{1}{c}{ Kebersihan handuk } & Jumlah & $\begin{array}{c}\text { Persentase } \\
(\boldsymbol{\%})\end{array}$ \\
\hline Cara meletakan handuk & & \\
Diletakan di sembarang tempat & 1 & 2,4 \\
Digantung dalam kamar & 15 & 35,7 \\
Dijemur di luar & 26 & 61,9 \\
\hline
\end{tabular}

Tabel 7. Hubungan tingkat kebersihan diri dengan kejadian pitiriasis versikolor

\begin{tabular}{cccccccc}
\hline $\begin{array}{c}\text { Tingkat } \\
\text { kebersihan diri }\end{array}$ & \multicolumn{3}{c}{ Pitiriasis versikolor } & \multicolumn{3}{c}{ Total } & Sig $(\boldsymbol{P})$ \\
\hline & ya & $\%$ & tidak & $\%$ & total & $\%$ & \\
Baik & 0 & 0,0 & 39 & 92,9 & 39 & 92,9 & 0,003 \\
Buruk & 2 & 4,8 & 1 & 2,4 & 3 & 7,1 & \\
Total & 2 & 42,6 & 40 & 95,2 & 42 & 100 & \\
\hline
\end{tabular}


Hasil korelasi antara higiene personal terhadap kejadian pitiriasis versikolor dengan menggunakan uji Fisher's exact test mendapatkan nilai signifikansi 0,003 $(<0,05)$ (Tabel 7) yang menunjukkan terdapat hubungan bermakna antara higiene personal dan pitiriasis versikolor.

\section{BAHASAN}

Berdasarkan penelitian yang dilakukan pada mahasiswa laki laki Fakultas Kedokteran Universitas Sam Ratulangi, dengan pemeriksaan mengunakan lampu Wood didapatkan hasil bahwa dari 42 subyek terdapat dua orang dinyatakan positif mengalami pitiriasis versikolor.

Dari dua subyek yang positif pitiriasis versikolor dengan pemeriksaan lampu Wood, didapatkan bahwa kejadian pitiriasis versikolor lebih banyak pada subyek dengan usia 18 dan 19 tahun. Hal ini selaras dengan penelitian Isa et $\mathrm{al}^{7}$ tentang profil pitiriasis versikolor di Poliklinik Kulit dan Kelamin RSUP Prof. Dr. R. D Kandou Manado periode Januari-Desember 2013 yang menunjukkan bahwa dari 36 kasus pitiriasis versikolor paling banyak menyerang kelompok usia 15-24 tahun dan 25-44 tahun (30,6\%). Demikain pula dengan hasil penelitian oleh Chigozie et $\mathrm{al}^{10}$ yang menyebutkan kelompok terbanyak ialah rentang usia 14-17 tahun (74\%). Hal ini tidak sejalan dengan penelitian yang dilakukan Jena et al $^{11}$ yang menyatakan bahwa frekuensi terbanyak pitiriasis versikolor didapatkan pada kelompok usia 8-12 tahun $(31,7 \%)$. Penelitian yang dilakukan Satria ${ }^{12}$ juga menyatakan bahwa responden terbanyak berada pada rentang 10-13 tahun $(36,5 \%)$. Perbedaan usia yang dipaparkan di atas dapat disebabkan karena pada penelitian ini hanya dibatasi pada usia remaja dewasa, dalam hal ini mahasiswa saja. Beberapa teori menyatakan bahwa kejadian pitiriasis versikolor dapat mengenai semua kelompok usia mulai dari anak sampai orang tua, tetapi lebih sering mengenai anak hingga dewasa muda karena umumnya individu dalam rentang usia ini lebih sering terpapar dengan faktor prediposisi pitiriasis versikolor seperti hiperhidrosis akibat aktivitas yang berlebihan ditambah kurangnya perilaku menjaga kebersihan diri.

Hasil penelitian ini menunjukkan bahwa kejadian pitiriasis versikolor lebih banyak terjadi pada subyek angkatan 2017 dan 2018. Hal ini berhubungan dengan tingkat kebersihan diri. Tingkat kebersihan diri didapatkan hasil dikategorikan baik hampir sebagian besar yaitu berjumlah 39 subyek dan yang dikategorikan buruk hanya 3 orang. Hasil penelitian ini sejalan dengan penelitian yang dilakukan oleh Suprianto dan Purwaningsih ${ }^{15}$ yang menyatakan adanya hubungan bermakna antara kebiasaan higiene dengan kejadian pitiriasis versikolor. Responden dengan kebiasaan mandi yang buruk berisiko 65,057 kali terinfeksi pitiriasis versikolor dibandingkan dengan yang mempunyai kebiasaan mandi baik.

Dari hasil penelitian didapatkan bahwa yang mengalami pitiriasis versikolor sebanyak dua subyek dan keduanya memiliki tingkat kebersihan diri yang buruk $(7,1 \%)$ sedangkan subyek dengan kebersihan diri baik yang terbanyak (92,9\%). Hasil ini sesuai dengan teori hubungan antara tingkat kebersihan diri dengan kejadian pitiriasis versikolor dimana kebersihan diri yang kurang baik dapat menjadi salah satu faktor risiko terjadinya pitiriasis versikolor. Kebersihan diri yang buruk dapat menjadi alasan mudahnya seseorang mengalami penyakit kulit yang disebabkan oleh jamur seperti pitiriasis versikolor karena kulit tidak bersih dan tidak terawat merupakan tempat yang baik bagi bakteri dan jamur untuk hidup dan berkembang sampai pada akhirnya menyebabkan penyakit kulit. ${ }^{1,3}$

Hasil uji Fisher Exact Test pada penelitian ini mendapatkan adanya hubungan bermakna antara higiene personal dengan kejadian pitiriasis versikolor pada mahasiswa laki-laki Fakultas Kedokteran Universitas Sam Ratulangi $(P=0,003)$.

\section{SIMPULAN}

Berdasarkan hasil penelitian ini dapat disimpulkan bahwa terdapat hubungan bermakna antara higiene personal dengan 
kejadian pitiriasis versikolor pada mahasiswa laki-laki Fakultas Kedokteran Universitas Sam Ratulangi.

\section{SARAN}

Penelitian ini dapat dikembangkan tidak hanya sebatas pada usia atau responden mahasiswa tertentu saja agar lebih banyak menggali informasi mengenai faktor risiko dan penyebab pitiriasis versikolor.

\section{DAFTAR PUSTAKA}

1. Kumar Rai M, Wankhade S. Tinea versicolor - an epidemiology. J Microb Biochem Technol. 2009;1(1):51-6.

2. Siregar RS. Penyakit Jamur Kulit (2nd ed). Jakarta: EGC, 2002; p. 8-9.

3. Harahap M. Ilmu Penyakit Kulit. Jakarta: Hipokrates, 2000; p. 73-4.

4. Menaldi SLSW. Ilmu Penyakit Kulit dan Kelamin. Jakarta: Fakultas Kedokteran Universitas Indonesia, 2017; p. 22-3.

5. Meera G, Thilak S, Joshua J. A study of 200 cases of pityriasis versicolor: the distribution of age, gender, blood group, lesion morphology, hemoglobin levels, cholesterol levels and diabetic status. Int J Res Dermatol. 2017; 3(1):20-3.

6. Partogi, Donna. Pityriasis versikolor dan diagnosis bandingnya (Ruam-ruam bercak putih pada kulit). Medan: Departemen Ilmu Kesehatan Kulit dan Kelamin FK USU, 2008.

7. Isa DYF, Niode NJ, Pandaleke HEJ. Profil Pitiriasis Versikolor di Poliklinik Kulit dan Kelamin RSUP Prof. Dr. R. D. Kandou Manado periode JanuariDesember 2013. eCl. 2016;4:2-6.
8. Siregar RS. Atlas Berwarna Saripati Penyakit Kulit (3rd ed). Jakarta: EGC, 2015; p. 10-2.

9. Rasool HBA. Importance of personal hygiene. Pharm Anal Acta. 2012;3 (8):4172.

10. Uneke C, Ngwu B, Egemba O. Tinea Capitis and pytiriasis versicolor infections among school children in the South- Eastern Nigeria: The Public Health Implications. The Internet Journal of Dermatology. 2006;4(2):1-7.

11. Jena DK, Sengupta S, Dwari BC, Ram MK. Pytiriasis versicolor in the pediatric age group. Indian Journal of Dermatology, Venerology, and Leprology. 2006;71(4):259-61.

12. Radisu AS. Distribusi kejadian tinea versikolor pada anak SDN 53 Sungai Raya Kabupaten Kubu Raya berdasarkan karakteristik dan faktor resiko. Pontianak: Universitas Tanjung Pura; 2012.

13. Scope A, Halpern AC. Diagnostic procedures and devices. In: Wolff $\mathrm{K}$, Goldsmith LA, Katz Si, Gilchrest BA, Paller AS, Leffel DJ, editors. Fitzpatrick's Dermatology in General Medicine (8th ed). New York: McGraw Hill Co, 2012; p. 40-1.

14. Gupta KL, Singhi MK. Wood's Lamp. Indian J Dermatol Venereol Leprol 2004; 70:131-5.

15. Supriyanto, Purwaningsih I. Personal hygiene terhadap infeksi pityriasis versikolor pada nelayan di Desa Panjajap Kecamatan Pemangkat. Jurnal Laboratorium Khatulistiwa. 2017;1(1). 